Digital Press Social Sciences and Humanities

The Social Dimensions' Aspects of Sustainable Tourism Development Analysis: A Systematic Literature Review

Agusta Ika Prihanti Nugraheni, Tri Kuntoro Priyambodo, Bayu Sutikno and Hendrie Adji Kusworo

Proceeding of Indonesia Heritage Tourism Forum 2019 (IHTF 2019)

Dewi Pratika Ayu Dhira Pradati (eds) 


\title{
The Social Dimensions' Aspects of Sustainable Tourism Development Analysis: A Systematic Literature Review
}

\author{
Kusworo ${ }^{1}$ \\ 1 Tourist Studies Program, Graduate School of Universitas Gadjah Mada, Yogyakarta, Indonesia \\ 2 Faculty of Economics and Business, Universitas Gadjah Mada, Yogyakarta, Indonesia \\ *e-mail: mastri@ugm.ac.id
}

Agusta Ika Prihanti Nugraheni ${ }^{1}$, Tri Kuntoro Priyambodo ${ }^{1 *}$, Bayu Sutikno ${ }^{2}$, and Hendrie Adji

\begin{abstract}
There is a synergistic potential between heritage and tourism which can offer a type of special interest tourism. However, despite the potential, it also brings out conflicts that result in negative socio-cultural impacts. Therefore, sustainability issues should be considered in developing heritage tourism. There are three dimensions incorporate in Sustainable Development, which are environment, economic, and social. As sustainable tourism was derived from sustainable development, thus the three dimensions of sustainable development are also applied in sustainable tourism development, especially in sustainable heritage tourism. Generally, the relationships between the three aspects of sustainable development are assumed to be compatible and mutually supportive. However, among the three dimensions of sustainable development, social sustainability is the least developed and often is proposed in relation to ecological or economic sustainability. There have been efforts to address and incorporate the social dimension of sustainability into standard setters, planners, and practitioners in many diverse areas such as forest certification, organic agriculture, conventional agriculture, urban and regional planning, corporate social and environmental management, reporting, and responsibility and fair-trade certification. However, there are still few studies of the social dimension in tourism development. To achieve sustainable tourism development, we cannot neglect the social dimension and only focuses on the economic and environmental dimensions. Social sustainability is not absolute or constant which has to be considered as a dynamic concept, which will change over time in a place. The purpose of this study exploring the key aspects of sustainable tourism development social dimension which is linked to theoretical and on how we should define and understand the fluid concept of the social dimension in tourism sustainability that can also be applied in heritage tourism. This research is using a systematic literature review to identify social dimension aspects or themes of sustainable development, sustainable tourism development, and sustainable heritage tourism. The preliminary findings show that there are few studies of the social dimension of sustainable tourism development. Therefore, it is rather difficult to obtain related articles of the social dimension, especially in the tourism subject fields. To this point, 160 works of literature were obtained and after screening, assessing, and selecting against the criteria for eligibility, there were 19 pieces of literature selected. Selected literature was reviewed to explore how the social dimension aspect in sustainable development debates is variously understood and how it constructs a social pillar. This research compiles a cross-disciplinary major theoretical concept from sustainable development, sustainable tourism development, heritage tourism, political sociology, economic theory, social theory, governance, and urban development to build a new multi-dimensional inquiry into the subject of social sustainability. Thus, this research gives a comprehension of the aspects of social sustainability which contributes to the improvement of the fluid concept of social tourism sustainability, especially in heritage tourism.
\end{abstract}

\section{Keywords}

social dimensions, social sustainability, sustainable heritage tourism, sustainable tourism

\section{Introduction}

Heritage Tourism is known as a form of special interest tourism, which according to McKercher and duCros (2002) is a type of tourism where heritage is the main part of shaping tourists' and travelers' motivations and experiences. Similar to other forms of tourism, heritage tourism also has positive and negative impacts. 
In general, tourism currently is recognized as activities that have many negative impacts, especially from environmental and social aspects despite its contributions to the economic aspects. Therefore, in order to minimize the negative impact of tourism activity, the concept of sustainable development at the end of the day was followed by the notion of sustainable tourism or sustainable tourism development. The sustainable tourism development concept itself was adopted from the sustainable development and tourism development paradigms (Welford, Ytterhus, \& Eligh, 1999). According to Dragouni (2017), sustainable development's concept provides a comprehensive view of economic, social, and heritage-related impacts of tourism on the destination because it proposed balanced small-scale and consensual initiatives, thus it is relevant to heritage tourism.

The three dimensions of Sustainable development are environmental, economic, and social. As sustainable tourism development was derived from sustainable development, thus the three dimensions of sustainable development are also applied in sustainable tourism development. Generally, the relationships between the three aspects of sustainable development are assumed to be compatible and mutually supportive (Boström, 2012). However, several scholars stated that generally many studies were focused on environmental and economic consideration rather than giving a more systematic focus on the social dimension (Agyeman, 2008; Bebbington \& Dillard, 2009; Marcuse, 1998). Because generally, environmental and economic dimensions have been seen to collaborate well in designing environmental policies and improvements (Blühdorn \& Welsh, 2007; Littig \& Grießler, 2005). Several studies indicate that the social dimension has the least attention or set aside completely (Agyeman, Bullard, \& Evans B., 2003; Agyeman \& Evans, 2004; Cuthill, 2010; Dillard, Dujon, \& King, 2009; Lehtonen, 2004; McKenzie, 2004). McKenzie as cited by Dempsey, Bramley, Power, \& Brown (2011) stated that among three dimensions of sustainable development, social sustainability is the least developed and frequently is proposed as a part of economic or ecological sustainability.

Sustainable development is extremely complex, so does sustainable tourism development. Currently, there is no common understanding of the concept definition, its inherent ambiguity and flexibility to interpret make it interesting. However, it is beneficial if there is a proliferation in the various framework and not one hegemonic theory because the different framework is needed for a different location, time frame, and situation (Boström, 2012). Although those frameworks do not automatically offer a clear picture, it still gives several different views of reality (Cuthill, 2010). Moreover, Dempsey et al cited by Dobson (1999) stated that social sustainability is not definite or uniform which has to be considered as a dynamic concept, which will change over time in a place".

This issue encourages us to study the work on social dimensions of sustainable tourism development and sum-ups the varied efforts to define, organize, and operationalize "social tourism sustainability". The purpose of this study to investigate the key aspects of the social dimension of sustainable tourism development which is related to theoretical and interests on how we should define and understand the fluid notion of social tourism sustainability.

\section{Methods}

This research is using a systematic literature review to investigate and collect the aspects or themes of the social dimension of sustainable development, especially in sustainable tourism development. This method is used to gain the answer to the initial steps of understanding the social dimension of sustainable tourism development and to portray the multifaceted, multidisciplinary and unbalanced condition that define sustainable tourism development (Farrell \& Twining-Ward, 2004; Nugraheni, Priyambodo, Kusworo, \& Sutikno, 2019; Pomering, Noble, \& Johnson, 2011; Tölkes, 2018). Petticrew \& Roberts (2006) stated that a systematic literature review gives a comprehensive search for relevant publications on a certain theme. A sequence of steps will guide a combination and critical assessment of the literature (Pickering \& Byrne, 2014). This method is applicable to disclose what is known and what is currently unknown about a subject and it is beneficial in outlining the scope of a field (Nugraheni et al., 2019; Petticrew \& Roberts, 2006; Pickering \& Byrne, 2014). Therefore, this study is using a systematic literature review approach since this method corresponds to the purpose of the study. Furthermore, this method is effective for managing diverse and transdisciplinary knowledge bases (Nugraheni et al., 2019; Petticrew \& Roberts, 2006; Pickering \& Byrne, 2014).

The systematic review process in this study was done in a sequence of different steps similar to Tölkes's (2018) steps in systematic review which was adapted from Petticrew and Roberts' (2006). The sevenstages-model of a systematic review is shown in Fig. 1. 


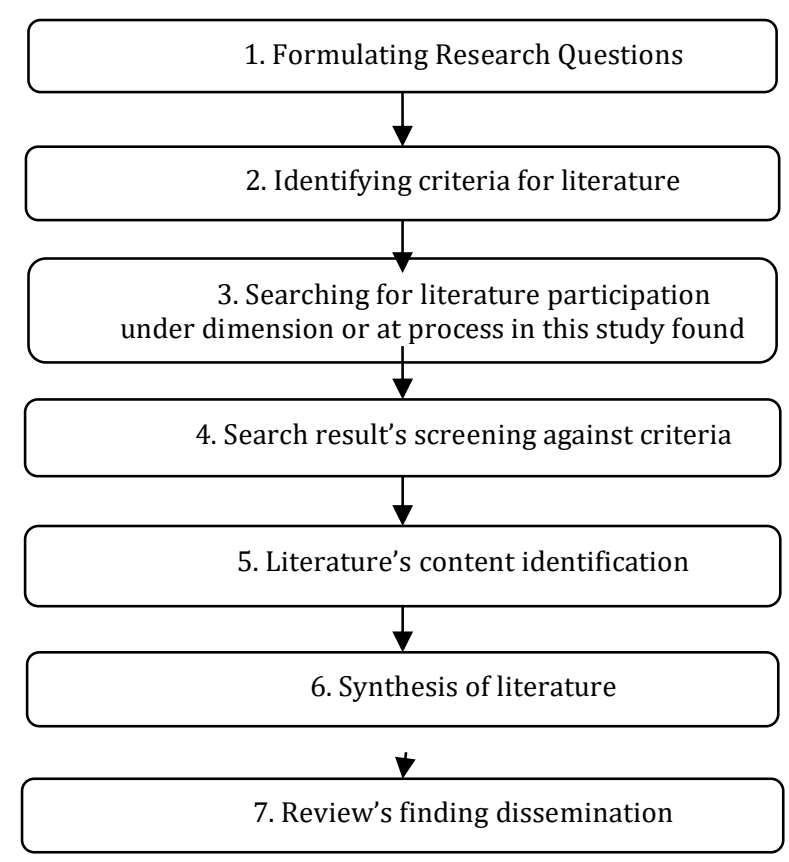

Fig. 1 The systematic review process

(Source: Adapted from Petticrew \& Roberts (2006); Tolkes, (2018))

The first step was defining research questions. As this study intends to investigate the main aspects of sustainable tourism development social dimension which is related to theoretical and interests on how we should define and comprehend the fluid notion of social tourism sustainability, thus the main research question in this literature review is: what are the social dimension aspects of sustainable tourism development that have been addressed in the literature?

In the second step, the type of studies and the criteria for this review were decided. The search procedure including the search terms, databases, and defining the inclusion and exclusion criteria for selecting literature were documented. Due to the limitation of research articles regarding the social dimension of Sustainable Development in the peer-reviewed journal, thus the literature review's range is expanded. which includes research articles, thesis, editorials, working papers, conference articles, books and chapters, and reports written in English language and Bahasa Indonesia to provide an overview of the body of knowledge and a basis upon which a social dimension of sustainable tourism development is constructed. The time frame was set to include all relevant articles, thesis, seminar presentations, and reports published from 1999 until 2019 (Nugraheni et al, 2019).

The literature was selected based on the following criteria: the social pillars, social indicators, social objectives, social aspects, or social dimensions that are discussed in Sustainable Development or Sustainable Tourism or Sustainable Tourism Development. The search terms were used to collect the relevant literature, which is used in title, keywords or abstracts with at least one of the terms: "social indicators", "social pillar", "social objectives", "social dimension", "social dimension" of "sustainable tourism development" or "sustainable tourism" or "sustainable development" (Nugraheni et al, 2019). The third step was searching the relevant literature which was searched in electronic databases such as Ebsco Host, Science Direct (Elsevier), Emerald, Scopus, Sage, Web of Science, and Proquest. Those electronic databases were accessed from the official UGM library homepage using the additional filters that are provided on the homepage. The literature was also searched by using scholar.google.com.

Then, in the fourth step, the results from the literature search were screened and selected for inclusion and exclusion criteria. There were 160 works of literature obtained as the search result and afterward the content was screened, assessed, and selected against the criteria for eligibility. As a result, 19 works of literature remained and 141 documents were eliminated because they did not review or mention the aspects social dimension of sustainable development or sustainable tourism development or because it is the same article. The process of collecting material resulted in a total of 19 works of literature and used for the literature review which was read thoroughly to understand and determine the content (Nugraheni et al, 2019). 
The fifth step based on Petticrew and Roberts (2006) and Tölkes (2018) was the literature's critical assessment. However, this step in this study is adapted into literature's content identification with a more thorough reading than the previous step. The social dimension aspects or themes of sustainable tourism development or sustainable development then were sought and identified from the articles that were selected from the previous step. Subsequently, in the sixth step, the social dimension aspects or themes that had been identified were synthesized and classified based on the similarity of description or meaning. In the next step, which is the seventh step is review's finding dissemination (Nugraheni et al, 2019).

\section{Result and Discussion}

There are few studies on the social dimension of sustainable tourism development. The social dimension of sustainable development discourses was not considered as important as the other two dimensions. In the 1990s, social sustainability was starting to gain significant acknowledgment. Since then, social sustainability studies were increasing although it still considered less in the tourism subject fields. Consequently, it is rather difficult to obtain related articles of the social dimension, especially in the tourism subject fields.

Tourism is a subject field that consists of different disciplines and subject fields and builds based on a synergy between those disciplines. The issues that are being debated in Tourism are similar to other subject fields concerned, such as in urban and rural studies (Harding \& Blokland, 2014; Woods, 2005). According to Graham (2005), ideas, concepts, and frameworks that were developed in different subject fields can be used as a method to combine and bridge the concept. The idea is that the summarized results that originate from each different subject field can be used by other research areas that are functioning as a bridge between different research areas. Therefore, according to Bramwell (2015), each research from different study fields was used to enhance their understanding in their own subject but also, they are contributing ideas, concepts, and frameworks for other fields, including in social theory in general. Moreover, Benton \& Redclift (1994) suggested those ideas form different subject fields can be combined to help us to understand across social sciences and even between the science the social sciences. Hence, aside from tourism literature, this study also incorporates various works of literature from other subject fields. The discussion regarding the social dimension's aspect in sustainable development that was found in most literature was discussing social dimension in general, or from geography, housing, supply chain, forestry literature, policy perspective. Generally, the discussion of the social dimension's aspect of tourism sustainable development was found in organizational literature such as UNWTO and GSTC.

This study obtained 160 pieces of literature which have one or more search terms in one or more of their section. After screening, assessing, and selecting against the criteria for eligibility, there were 19 works of literature selected. Selected literature was studied to investigate how the social dimension aspect in sustainable development debates is understood and how it constructs a social pillar. This process is shown in Fig. 2 below. 


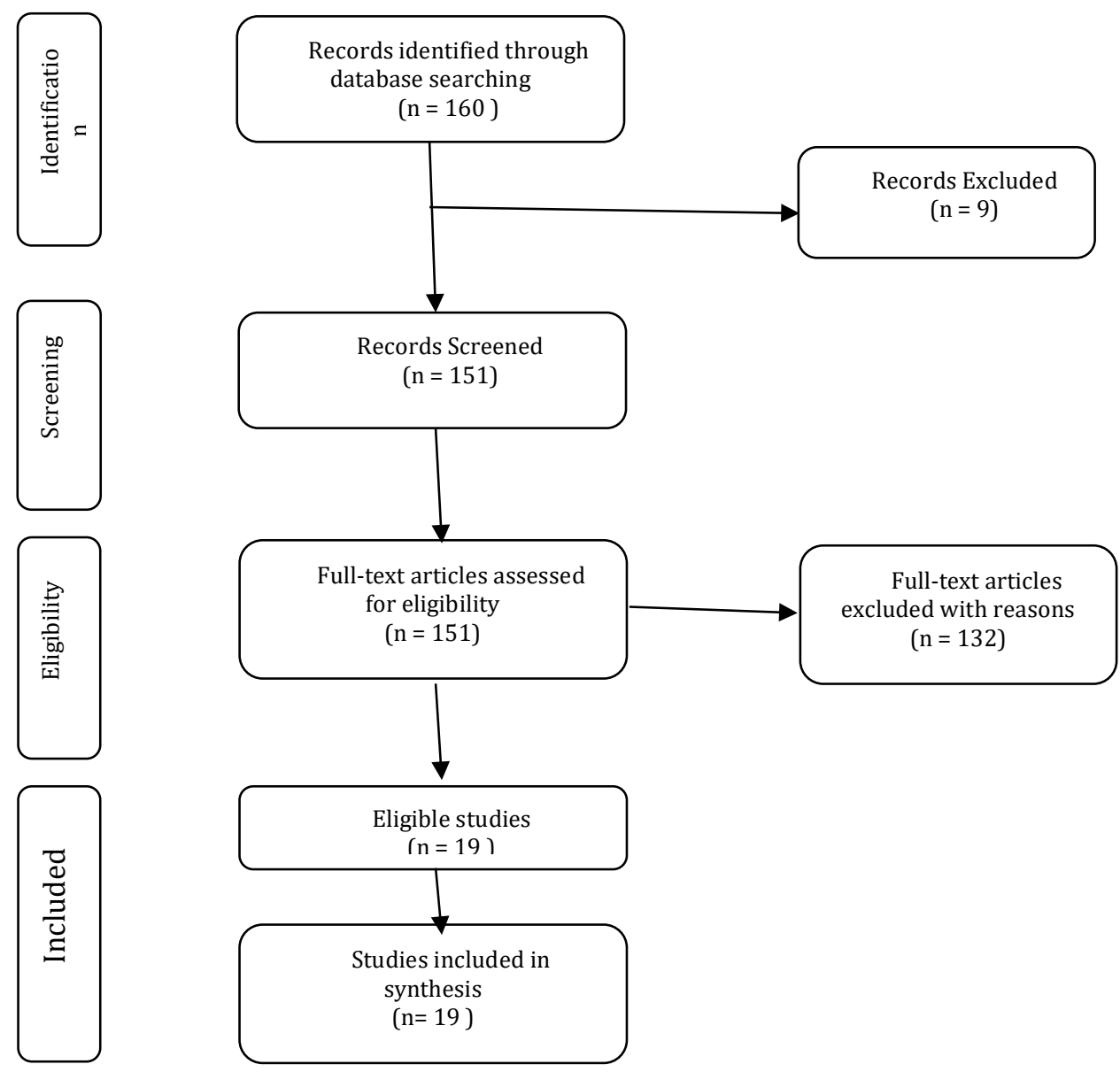

Fig. 2 The Systematic Literature review process

(Source: Adapted Tolkes, 2018)

The result of the systematic review process in this study discovered 25 social dimensions' aspects of sustainable development which were found in 22 sources, either from organizational and individuals authors (scholars) by identifying 160 articles. Those aspects are equality, employment, health, social cohesion, inclusion and coherence, education and knowledge, social infrastructure and housing, poverty, support for the community, accessibility by local residents to key assets, good governance, local purchasing (support the local entrepreneur and fair-trade), community impact or social impact, basic needs, quality of life and human well-being, public participation, decent work and better working condition, public safety, and security, protecting and enhancing cultural heritage, local identity, and assets, human rights (preventing exploitation), demography, hunger and nutrition, economic self-sufficiency, sustaining tourist satisfaction, individual autonomy and realization of personal potential, resources distributions that affect the ability of that society to flourish over time, and ethics (Nugraheni et al, 2019). 


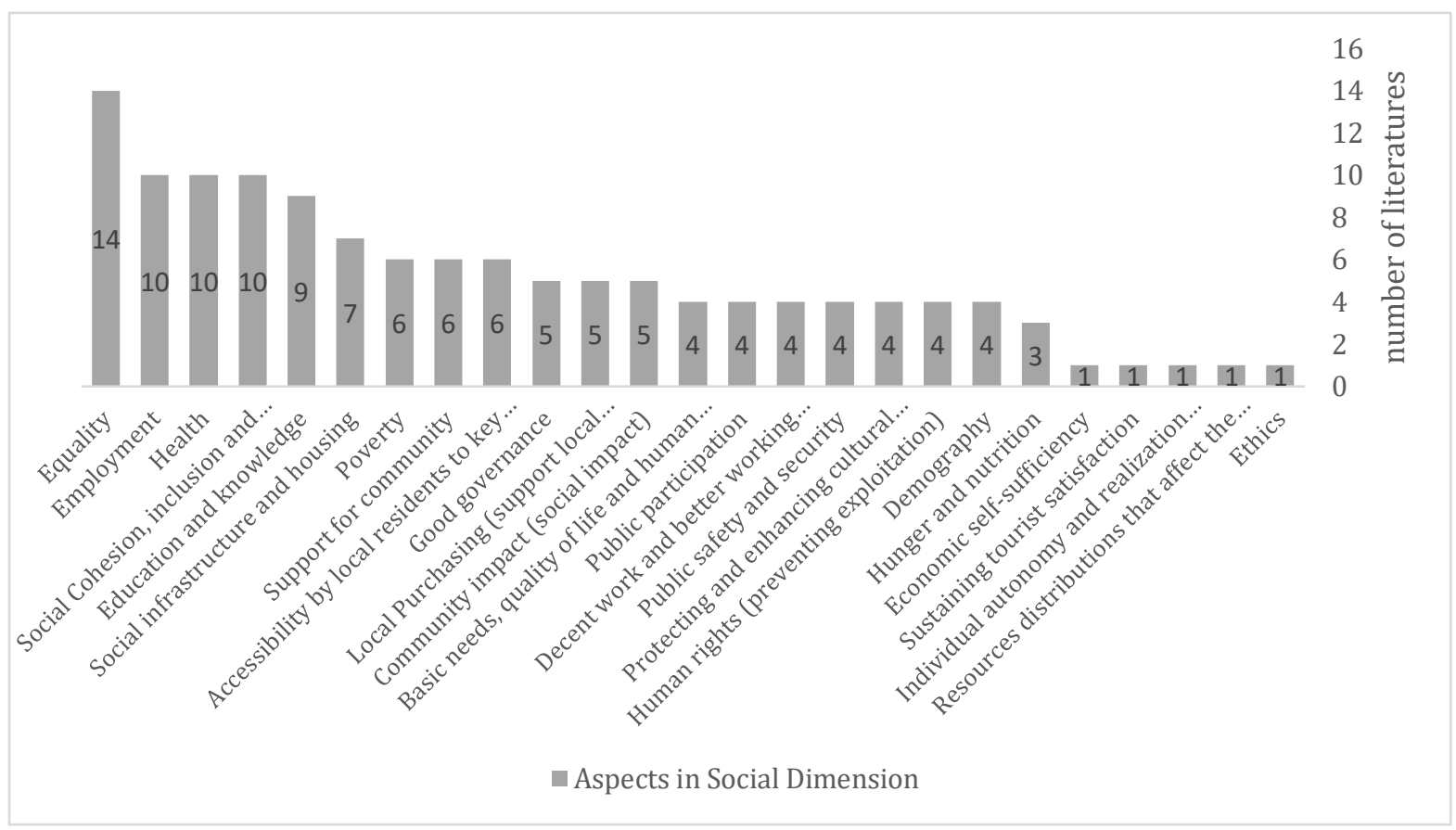

Fig. 3 The number of aspects and literature that incorporate these aspects in the social dimension

The most common aspect incorporate in the social dimension is equality, with 14 works of literature incorporate it in their social aspect classification. The term used for equality includes equity, social justice, and equity, gender equality, reducing equality, social, homogeneity, social equity, equal opportunity. Three aspects become the second most widely incorporated aspect of the social dimension. Those three aspects are employment, health, and also social cohesion, inclusion, and coherence. The term used for employment includes promoting full employment and decent work, a more flexible labor market, unemployment, access to goods, services and employment, availability of job opportunities, local employment, local career opportunities.

Terms used in relation to health aspects are health, investing in public health, health and safety, health and wellbeing, health and welfare, public health, and protecting human health. Terms used for social cohesion, inclusion, and coherence are promoting peaceful and inclusive societies, social capital, social inclusion of marginalized groups, social exclusion, social coherence, and social cohesion. Education and knowledge become the third most incorporated aspect in the social dimensions with nine literature mention them as part of social dimensions. The terms used are the propagation of knowledge, ensuring inclusive education, investing in knowledge and skills, education, literacy, promoting education, public awareness and training, tourism awareness, and education. Then, seven literature include social infrastructure and housing as aspects of social dimensions. The terms used similar to social infrastructure and housing are social infrastructure, shelter, townscape design, promoting human settlement, housing.

Three aspects were incorporated by six literature in their discussion of social dimensions, which are poverty, support for the community, and accessibility by residents to key assets. The terms used for poverty are eradication of poverty, poverty, combating poverty. The terms used for support for community are support for the community, community support, community services, citizenship, and service to others. While the terms used to discuss accessibility by residents to key assets are accessibility, access, local access, accessibility for tourist satisfaction

Good governance, local purchasing (support local entrepreneur and fair-trade), and community impact (social impact) were incorporated by five literature in their discussion of social dimensions. Other terms used for good governance are engaged government, democratic government, good governance, or just simply governance while local purchasing or support the local entrepreneur and fair trade were mentions as it is. Community impact (social impact) were mentions as effects of tourism on communities, local satisfaction with tourism, ability to fulfill psychological needs, the sustainability of the community.

Four literature mentioned the quality of life and human well-being, basic needs, decent work and better working condition, public safety, and security, public participation, human rights (preventing exploitation), protecting and enhancing cultural heritage, local identity, and assets, and demography. Basic needs, quality of life, and human well-being are also known as the local livelihood. While, the terms used in stating public 
participation are participation in governance and rulemaking, democratic civil society, community participation in tourism (community involvement and awareness). Public safety and security were also stated as safety, tourist security, local public safety, or security as in combating crime. While terms used to state protecting and enhancing cultural heritage, local identity and assets are cultural expressions, conserving built heritage (in sustaining cultural asset) and preservation of local characteristics. The other terms used to state human rights (preventing exploitation) are exploitation and harassment. Hunger and nutrition incorporated into three pieces of literature. While these aspects: economic self-sufficiency, individual autonomy and realization of personal potential, resource distributions that affect the ability of that society to flourish over time, sustaining tourist satisfaction, and ethics only incorporated in social dimension by one literature (Nugraheni et al, 2019).

Some scholars categorized those twenty-five aspects into several groups. Cuthill (2009) classifies social dimension aspects into four key components, which are social capital, social infrastructure, social justice, and equity, and also engaged governance. While Dempsey, Bramley, Power, and Brown (2011), identified and classified the social dimension of sustainable development in defining urban social sustainability into two factors, which are non-physical factors and predominantly physical factors. Both studies are in urban development studies. Littig \& Grissler (2005) categorized social dimensions of sustainability into three categories, which are basic needs and quality of life, social justice, and social coherence. Magis \& Shinn (2004) categorized four universal principles covering social sustainability: human well-being, equity, democratic government, and democratic civil society. According to McKenzie (2004), the key principles for social sustainability include equity, diversity, interconnectedness, and quality of life.

UNWTO (2004) and the Global Sustainable Tourism Council (2013, 2016a, 2016b) incorporate aspects of the social dimension in their indicator. However, they do not clearly separate the three pillars of sustainable tourism development. The social dimension is however perceived as a part of either environmental dimension or economic dimension. Moreover, UNWTO and GSTC approach in integrating the social dimension are blending into other dimensions but categorizing them into few principles.

\section{Conclusions}

There are more than 25 aspects of the social dimension. Some scholars categorized those aspects into 3 until 6 categories. Identification of these aspects provides an overview of how social sustainability as a concept is built. However, those aspects are not only derived from sustainable tourism development literature but also derived from other disciplines. All aspects are associated with basic needs and quality of life and good governance to achieve the ideal social condition and also the need for community participation. Since tourism is developed from diversified disciplines, the twenty-five aspects can be considered when developing a full understanding of the social dimension of sustainable tourism development. However, in developing a comprehensive understanding of the social dimension, it has to consider several conditions such as the condition of the tourist destination, the type of tourism to be developed, the culture of the host community, the political and regulation, etc. Therefore, the chosen aspects will be relevant to the current condition of the community. Especially, in developing heritage tourism, careful consideration of those aspects should be taken.

\section{References}

Agyeman, J. (2008). Toward a 'just' sustainability? Continuum, 22(6), 751-756. https://doi.org/10.1080/10304310802452487

Agyeman, J., Bullard, R., \& Evans B., (Eds.). (2003). Just Sustainabilities: Development in an Unequal World. Cambridge MA: MIT Press.

Agyeman, J., \& Evans, B. (2004). "Just sustainability": the emerging discourse of environmental justice in Britain? The Geographical Journal, 170(2), 155-164. https://doi.org/10.1111/j.0016-7398.2004.00117.x

Bebbington, J., \& Dillard, J. (2009). Social sustainability: an organizational-level analysis. In J. Dillard, V. Dujon, \& M. King. (Eds.), Understanding the Social Dimension of Sustainability (pp. 157-173). New 
York: Routledge.

Benton, T., \& Redclift, M. (1994). Introduction. In M. Redclift. \& T. Benton. (Eds.), Social theory and the global environment (pp. 1-27). London: Routledge.

Blühdorn, I., \& Welsh, I. (2007). Eco-politics beyond the paradigm of sustainability: A conceptual framework and research agenda. Environmental Politics, 16(2), 185-205. https://doi.org/10.1080/09644010701211650

Boström, M. (2012). A missing pillar? Challenges in theorizing and practicing social sustainability: introduction to the special issue. Sustainability: Science, Practice and Policy, 8(1), 3-14. https://doi.org/10.1080/15487733.2012.11908080

Bramwell, B. (2015). Theoretical activity in sustainable tourism research. Annals of Tourism Research, 54, 204218. https://doi.org/10.1016/j.annals.2015.07.005

Cuthill, M. (2010). Strengthening the 'social' in sustainable development: Developing a conceptual framework for social sustainability in a rapid urban growth region in Australia. Sustainable Development, 18(6), 362373. https://doi.org/10.1002/sd.397

Dempsey, N., Bramley, G., Power, S., \& Brown, C. (2011). The social dimension of sustainable development: Defining urban social sustainability. Sustainable Development, 19(5), 289-300. https://doi.org/10.1002/sd.417

Dillard, J., Dujon, V., \& King, M. (Eds. . (2009). Understanding the Social Dimension of Sustainability. New York: Routledge.

Dobson, A. (Ed. . (1999). Fairness and Futurity: Essays on Environmental Sustainability and Social Justice. New York: Oxford University Press.

Dragouni, M. (2017). Sustainable heritage tourism: Towards a community-led approach (University College London). Retrieved from https://discovery.ucl.ac.uk/id/eprint/10025949/

Farrell, B. H., \& Twining-Ward, L. (2004). Reconceptualizing Tourism. Annals of Tourism Research, 31(2), 274-295. https://doi.org/10.1016/j.annals.2003.12.002

Global Sustainable Tourism Council. (2013). GSTC destination criteria. Retrieved from https://www.gstcouncil.org/wp-content/uploads/2013/11/Dest-_CRITERIA_and_INDICATORS_6-914.pdf

Global Sustainable Tourism Council. (2016a). GSTC Industry criteria: Suggested Performance Indicators for Hotels and Accommodations. Retrieved from https:/www.gstcouncil.org/wp-content/uploads/GSTCIndustry-Criteria-for-Hotels-with-indicators-Dec-2016.pdf

Global Sustainable Tourism Council. (2016b). GSTC Industry criteria: Suggested Performance Indicators for Tour Operators. Retrieved from https://www.gstcouncil.org/wp-content/uploads/GSTC-Industry-Criteriafor-Tour-Operators-with-indicators-Dec-2016.pdf

Graham, E. (2005). Theory and theorizing. In N. Castree, A. Rogers, \& D. Sherman (Eds.), Questioning Geography: Fundamental Debates (pp. 258-273). Oxford: Blackwell, USA.

Harding, A., \& Blokland, T. (2014). Urban theory. A critical introduction to power, cities and urbanism in the 21 st century. London: Sage.

Lehtonen, M. (2004). The environmental-social interface of sustainable development: capabilities, social capital, institutions. Ecological Economics, 49(2), 199-214. https://doi.org/10.1016/j.ecolecon.2004.03.019 
Littig, B., \& Grießler, E. (2005). Social sustainability: a catchword between political pragmatism and social theory. International Journal of Sustainable Development, 8(1), 65-79. Retrieved from https://www.ihs.ac.at/fileadmin/public/soziologie/test2.pdf

Magis, K., \& Shinn, C. (2004). Emergent principles of social sustainability. In J. Dillard, V. Dujon, \& V. King (Eds.), Understanding the Social Dimension of Sustainability (pp. 15-44). https://doi.org/https://doi.org/10.22334/jbhost.v5i2

Marcuse, P. (1998). Sustainability is not enough. Environment and Urbanization, 10(2), 103-111. https://doi.org/https://doi.org/10.1177

McKenzie, S. (2004). Social sustainability: towards some definitions. In Hawke Research Institute Working Paper Series, No 27. Magill, South Australia.

McKercher, B., \& DuCros, H. (2002). Cultural Tourism: The partnership between tourism and cultural heritage management. New York: The Hawthorn Hospitality Press.

Nugraheni, A. I. P., Priyambodo, T. K., Kusworo, H. A., \& Sutikno, B. (2019). The social dimension of sustainable development: defining tourism social sustainability. Proceeding of the 1st International Conference on Engineering, 18-19. Labuan Bajo, Nusa Tenggara Timur, Indonesia, Oktober 2019: Science and Commerce.

Petticrew, M., \& Roberts, H. (2006). Systematic reviews in the social sciences: A practical guide. Malden: Blackwell Publishing.

Pickering, C., \& Byrne, J. (2014). The benefits of publishing systematic quantitative literature reviews for PhD candidates and other early-career researchers. Higher Education Research \& Development, 33(3), 534548. https://doi.org/10.1080/07294360.2013.841651

Pomering, A., Noble, G., \& Johnson, L. W. (2011). Conceptualising a contemporary marketing mix for sustainable tourism. Journal of Sustainable Tourism, 19(8), 953-969. https://doi.org/10.1080/09669582.2011.584625

Tölkes, C. (2018). Sustainability communication in tourism - A literature review. Tourism Management Perspectives, 27, 10-21. https://doi.org/10.1016/j.tmp.2018.04.002

UNWTO. (2004). Indicators of sustainable development for tourism destination: a guidebook. Madrid, Spain.

Welford, R., Ytterhus, B., \& Eligh, J. (1999). Tourism and sustainable development: an analysis of policy and guidelines for managing provision and consumption. Sustainable Development, 7(4), 165-177. https://doi.org/https://doi.org/10.1002/(SICI)1099-1719(199911)7:4

Woods, M. (2005). Rural geography. Processes, responses and experiences in rural restructuring. London: Sage. 